\title{
I.UMIRUNC
}

\section{KANDUNGAN GIZI DAN BAHAN AKTIF FENOL DAUN BANGUN-BANGUN (Coleus amboinicus L.) PADA METODA PENGERINGAN YANG BERBEDA}

\author{
Ramond Siregar ${ }^{1}$, Nelzi Fati ${ }^{1}$ dan Yun Sondang ${ }^{2}$ \\ ${ }^{1}$ Program Studi Budi Daya Ternak Politeknik Pertanian Negeri Payakumbuh \\ ${ }^{2}$ Program Studi Budidaya Tanaman Pangan Politeknik Pertanian Negeri Payakumbuh \\ Jl. Raya Negara Km. 7 Tanjung Pati, 26271, Payakumbuh \\ Korespondensi: garr_fams@yahoo.co.id
}

\author{
Diterima : 06 Agustus 2019 \\ Disetujui : 30 Agustus 2019 \\ Diterbitkan : 31 Agustus 2019
}

\begin{abstract}
ABSTRAK
Tanaman bangun-bangun (Coleus amboinicus L.) mengandung kalium, karbohidrat, dan energi yang tinggi, serta minyak atsiri dengan kandungan carvakrol, isoprofil-o-kresol dan fenol. Secara farmakologi, tanaman ini mengandung beberapa bahan aktif yang bersifat menghilangkan sakit, penurun panas, dan antiseptik, penyegar, dan penambah semangat. Cara pengeringan berpengaruh terhadap tanaman, selain itu bahwa pengeringan bahan tanaman yang kurang tepat akan merusak komponen bahan aktif sehingga menurunkan mutunya. Penelitian ini dilakukan di Politeknik Pertanian Negeri Payakumbuh, bahan yang digunakan adalah daun bangun-bangun segar yang dikeringkan dengan 4 (empat) cara pengeringan yaitu: kipas angin, oven, udara dan matahari. Daun bangun-bangun yang telah dikeringkan selanjutnya dianalisa di laboratorium kimia. Percobaan dilakukan menggunakan Rancangan Acak Lengkap (RAL) dengan 4 perlakuan dan 5 ulangan. Hasil analisa laboratorium kimia menunjukkan bahwa perlakuan metode pengeringan daun bangun-bangun berpengaruh sangat nyata pada kandungan protein kasar, serat kasar dan fenol. Pengeringan kering matahari menunjukkan kadar protein tertinggi $(20,48 \%)$ dan pengeringan kipas angin menunjukkan kadar protein terendah $(12,65 \%)$. Pengeringan kering oven menunjukkan kadar serat kasar tertinggi $(17,21 \%)$ dan kipas angin menunjukkan kadar serat kasar terendah $(13,05 \%)$. Pengeringan kipas angin menunjukkan kadar total fenol tertinggi $(8.400 \mathrm{ppm})$ dan oven menunjukkan terendah $(2.100 \mathrm{ppm})$.
\end{abstract}

\section{Kata Kunci: daun bangun-bangun, fenol}

\begin{abstract}
Plants bangun-bangun (coleus amboinicus L) rich in potassium as well as essential oils karvakrol, isoprofil-o-kresol and fenol. These plants contain pharmaceutically active ingredients that areanalgesic, antifever, antiseptic, refresher and braced up. Un appropriate plant drying affected active raw and decrease a plant quality. the material used was bangun-bangun leaves which were dried in 4 (four) ways of drying namely: fans, ovens, air and sun. The leaves of bangun-bangn that have been dried are then analyzed in a chemical laboratory. The experiment was carried out using a Completely Randomized Design with 4 treatments and 5 replications. The results of this research
\end{abstract}




\section{I.UMIRUNC}

show that the treatment method of drying leaves of bangun-bangun has a very significant effect on the content of crude protein, crude fiber and phenol. Dry sun drying shows the highest protein content (20.48\%) and fan drying shows the lowest protein content (12.65\%). Dry oven drying shows the highest crude fiber content (17.21\%) and the fan shows the lowest crude fiber content (13.05\%). Fan drying shows the highest total phenol content (8,400 ppm) and the oven shows the lowest $(2,100$ ppm).

\section{Keywords: bangun-bangun, nutrients, crude protein}

\section{PENDAHULUAN}

Indonesia dengan kekayaan keanekaragaman hayatinya mempunyai potensi yang cukup besar untuk menyediakan obat alami untuk ternak. Tanaman bangunbangun (Coleus amboinicus L.) merupakan salah satu tanaman obat yang banyak khasiatnya. Penggunaan tanaman ini lebih bertujuan untuk meningkatkan kesehatan ternak, namun masih sedikit informasi tentang manfaat untuk peningkatan produksi pada ternak terutama dalam meningkatkan bobot sapih anak pada ternak kambing.

Tanaman bangun-bangun berasal dari daerah Sumatera Utara dan selanjutnya dibawa oleh pendatang ke daerah Sumatera Barat. Tanaman bangun-bangun sudah lama dikenal dalam masyarakat Tapanuli sebagai menu sayur-sayuran sehari-hari untuk meningkatkan stamina dan memperlancar produksi air susu pada ibu melahirkan. Daunnya memiliki aroma tertentu sehingga disebut tanaman aromatik dan mengandung minyak atsiri.

Siregar, Wahono, Fati, dan Sondang (2013) menyatakan hasil identifikasi tanaman bangun-bangun di tiga wilayah Sumatera Barat menunjukkan ciri-ciri morfologi yang hampir sama, hal ini disebabkan syarat tumbuh ketiga tempat hampir sama, namun wilayah Padang Panjang merupakan tempat yang paling memenuhi syarat tumbuh tanaman ini. Hal ini dapat dilihat dari kondisi lingkungan, tinggi tanaman (50$100 \mathrm{~cm})$, jumlah cabang per tanaman (9-24 buah), panjang daun $(5-8 \mathrm{~cm})$, lebar daun (5-8 cm), panjang tangkai daun $(4-7 \mathrm{~cm})$ dan jumlah daun per tanaman (97-206 buah).

Cara pengeringan berpengaruh terhadap karakteristik mutu simplisia tanaman obat sambiloto (Manoi, 2006). Rusli dan Darmawan (2004) menyatakan bahwa pengeringan bahan tanaman yang kurang tepat akan merusak komponen bahan aktif sehingga menurunkan mutunya. Disimpulkan bahwa kandungan bahan aktif yang terdapat dalam tanaman sangat dipengaruhi oleh proses pengeringan. Pramono, (1985) 


\section{I.UMIRUNC}

dalam Manoi (2006) menyatakan pengeringan terhadap bunga-bungaan dan daundaunan harus dijaga agar warna dan aroma tanaman aslinya tidak berubah. Secara umum daun herba dan bunga dapat dikeringkan pada suhu $2-40^{\circ} \mathrm{C}$.

\section{METODE PENELITIAN}

Penelitian dilaksanakan mulai bulan Juli sampai Agustus tahun 2018. Analisa kandungan gizi dan bahan aktif dilakukan di laboratorium Kimia Politeknik Pertanian Negeri Payakumbuh. Bahan terdiri dari daun bangun-bangun segar asal Sumatera Barat dan bahan kimia untuk pengujian bahan aktif dan nilai gizi. Alat yang digunakan gunting stek, oven, timbangan digital, ember kipas angin, alas plastik dan alat-alat laboratorium.

Percobaan dilakukan menggunakan Rancangan Acak Lengkap (RAL) dengan 4 perlakuan dan 5 ulangan. Perlakuan metode pengeringan:
A $=$ Pengeringan dengan kipas angin (5 hari)
$\mathrm{B}=$ Pengeringan dengan oven suhu $60^{\circ} \mathrm{C}(5 \mathrm{jam})$
$\mathrm{C}=$ Pengeringan dengan kering udara (5 hari)
D = Pengeringan dengan matahari (5 hari)

Daun tanaman bangun-bangun yang telah dibudidayakan sebelumnya disiapkan dan dilakukan pengeringan sesuai perlakuan. Setelah dikeringkan dengan lama waktu yang sudah ditentukan, selanjutnya dilakukan pengujian kandungan protein kasar, serat kasar dan fenol.

\section{HASIL DAN PEMBAHASAN}

Tabel 1. Rataan protein kasar, serat kasar dan kadar fenol daun bangun-bangun

\begin{tabular}{cccc}
\hline Perlakuan & Protein Kasar $(\%)$ & Serat Kasar $(\%)$ & Total Fenol $(\mathrm{ppm})$ \\
\hline B1 & $12,65 \mathrm{a}$ & $13,05 \mathrm{a}$ & $8.400 \mathrm{c}$ \\
B2 & $15,76 \mathrm{~b}$ & $17,21 \mathrm{c}$ & $2.100 \mathrm{a}$ \\
B3 & $18,45 \mathrm{c}$ & $16,78 \mathrm{c}$ & $5.000 \mathrm{~b}$ \\
B4 & $20,48 \mathrm{~d}$ & $14,91 \mathrm{~b}$ & $3.100 \mathrm{a}$ \\
\hline
\end{tabular}

Angka-angka pada kolom yang diikuti oleh huruf kecil yang berbeda menunjukkan perbedaan yang sangat nyata $(\mathrm{P}<0,01)$

Ket: B1= kering kipas angin, B2 = kering oven, B3 = kering udara, B4 = kering matahari 


\section{I.UMIRUNC}

\section{Protein Kasar}

Perlakuan metode pengeringan daun bangun-bangun berpengaruh sangat nyata $(\mathrm{P}<0,01)$ terhadap kandungan protein kasar. Rataan protein kasar selama penelitian berkisar $12,65 \%-20,48 \%$. Berdasarkan hasil sidik ragam protein kasar sangat nyata $(\mathrm{P}<0,01)$ dipengaruhi oleh metode pengeringan. Hasil Uji Jarak Berganda Duncan ternyata metode pengeringan dengan kering matahari menunjukkan kadar protein yang tertinggi $(20,48 \%)$ dan metode pengeringan dengan kipas angin menunjukkan kadar protein yang terendah $(12,65 \%)$.



\section{Serat Kasar}

Perlakuan metode pengeringan daun bangun-bangun berpengaruh sangat nyata $(\mathrm{P}<0,01)$ terhadap kandungan serat kasar. Rataan serat kasar selama penelitian berkisar $13,05 \%-17,21 \%$.

Berdasarkan hasil sidik ragam serat kasar sangat nyata $(\mathrm{P}<0,01)$ dipengaruhi oleh metode pengeringan. Hasil Uji Jarak Berganda Duncan ternyata metode pengeringan dengan kering oven menunjukkan kadar serat kasar yang tertinggi $(17,21 \%)$ dan metode pengeringan dengan kipas angin menunjukkan kadar serat kasar yang terendah $(13,05 \%)$. 


\section{I.UMIRUNC}

\section{0}

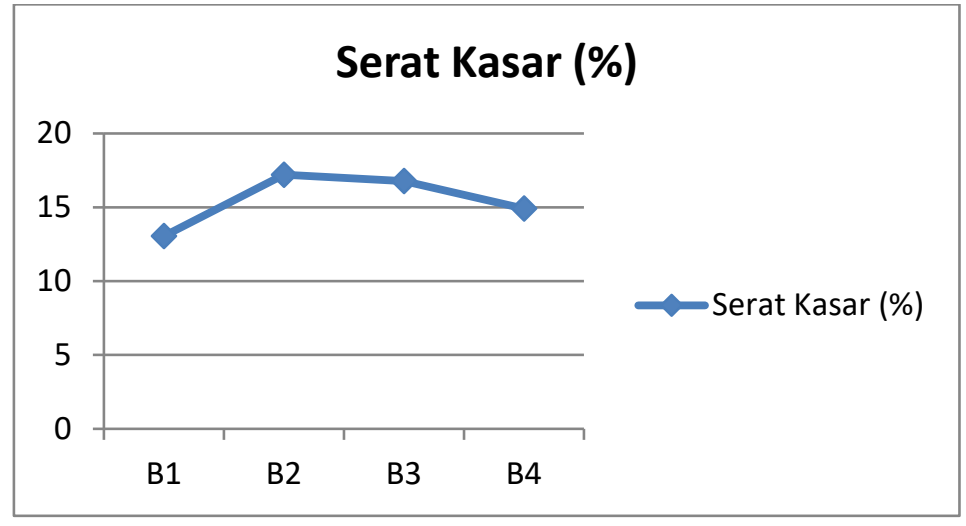

\section{Fenol}

Perlakuan metode pengeringan daun bangun-bangun berpengaruh sangat nyata $(\mathrm{P}<0,01)$ terhadap kandungan total fenol. Rataan total fenol daun bangun-bangun berkisar 2100 ppm-8400 ppm. Berdasarkan hasil sidik ragam total fenol sangat nyata $(\mathrm{P}<0,01)$ dipengaruhi oleh metode pengeringan. Hasil Uji jarak Berganda Duncan ternyata metode pengeringan dengan kering kipas angin menunjukkan kadar total fenol yang tertinggi $(8.400 \mathrm{ppm})$ dan metode pengeringan dengan oven menunjukkan kadar fenol yang terendah (2.100 ppm).

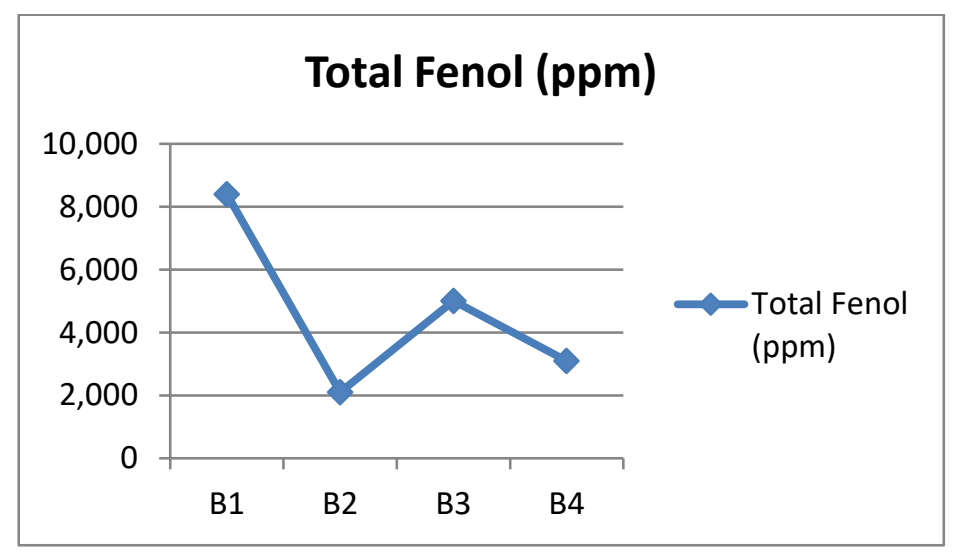

Hasil penelitian menunjukkan bahwa total fenol dengan pengeringan kering kipas angin lebih tinggi dibandingkan dengan pengeringan kering udara, oven dan sinar matahari. Hal ini terjadi karena pengeringan kering kipas angin mempunyai suhu yang lebih rendah dibandingkan pengeringan menggunakan kering udara, dibawah sinar matahari dan oven. Luximon-Ramma et al. (2002), menyatakan bahwa perbedaan kandungan fenol antara ekstrak yang berasal dari sampel segar dan kering disebabkan akibat proses pengeringan. Senyawa fenol memiliki sifat mudah teroksidasi dan sensitif 


\section{I.UMIBUNG}

terhadap perlakuan panas, sehingga dengan adanya proses pengeringan dengan sinar matahari dapat menurunkan kandungan senyawa fenol.

Suhu optimum pengeringan untuk mendapat kadar total fenol maksimum adalah $60{ }^{\circ} \mathrm{C}$. Pengeringan lebih tinggi dari $60{ }^{\circ} \mathrm{C}$ setelah 4 menit maka fenol akan rusak dan kadarnya cenderung menurun (Sari dkk., 2012). Liyana and Shahidi (2005), menyatakan bahwa ada hubungan antara suhu dan senyawa fenolik, kandungan senyawa fenolik menurun seiring dengan peningkatan suhu yang lebih tinggi, hal ini disebabkan dekomposisi senyawa fenolik.

Senyawa fenol, seperti flavonoid dapat dipengaruhi oleh temperatur dan radiasi. Peningkatan konsentrasi flavonoid seiring dengan penurunan suhu dan intensitas radiasi (Schmidt et al., 2009). Hal inilah yang menyebabkan kandungan total fenol pada pengeringan dibawah sinar matahari paling sedikit dibandingkan dengan pengeringan mengunakan kipas angin dan kering udara.

Wahyuni dkk. (2014) dalam penelitiannya mengatakan bahwa pengeringan dengan oven $45{ }^{\circ} \mathrm{C}$ memberikan hasil terbaik pada nilai susut pengeringan, kadar abu total, kadar abu tidak larut asam, kadar sari larut air dan kadar sari larut ethanol. Sementara itu Masduqi A.F dkk. (2014) mengatakan efek metoda pengeringan dengan kering angin paling tertinggi dalam mendapatkan senyawa fenol $1.656,3$ ppm pada rumput laut. Rivai, H. dkk. (2010) menyatakan bahwa pengeringan angin pada suhu 25 ${ }^{0} \mathrm{C}$ menghasilkan kadar senyawa fenolat dan antioksidan tertinggi.

\section{KESIMPULAN}

1. Metoda pengeringan pada daun bangun-bangun berpengaruh sangat nyata terhadap kandungan protein kasar, serat kasar dan fenol.

2. Pengeringan kering matahari menunjukkan kadar protein tertinggi $(20,48 \%)$ dan pengeringan kipas angin menunjukkan kadar protein terendah $(12,65 \%)$.

3. Pengeringan kering oven menunjukkan kadar serat kasar tertinggi $(17,21 \%)$ dan kipas angin menunjukkan kadar serat kasar terendah $(13,05 \%)$.

4. Pengeringan kipas angin menunjukkan kadar total fenol tertinggi $(8.400 \mathrm{ppm})$ dan oven menunjukkan terendah (2.100 ppm) 


\section{I.UMIBUNG}

\section{DAFTAR PUSTAKA}

Liyana-Pathirana, C. and F. Shahidi. 2005. Optimization of extractionof Phenolic compounds from wheat using response surface methodology. Food Chemistry 93:47-56.

Luximom-Ramma, A., T. Bahorun, M.A. Soobrate, O.I. Aruoma. 2002. Antioxidant activities of Phenolic, Proanthocyanidin, and Flavonoid components in extract of Cassia fistula. J. Agric.Food Chem.50:5042-5047.

Manoi, F. 2006. Pengaruh cara pengeringan terhadap mutu simplisia Sambiloto. Balai Penelitian Tanaman Rempah dan Aromatik. Bul. Littro. Vol. XVII, No. 1(1-5).

Masduki, A.F., Munifatul, I., Erna, P. 2014. Efek Metoda Pengeringan Terhadap Kandungan Bahan Kimia Dalam Rumput Laut., Bulletin Anatomi dan Fisiologi Vol. XXII, No. 1, 2014

Rivai, H., Hazli, N., Hamzar, S., dan Amri, B., (2010). Pengaruh cara pengeringan terhadap perolehan ekstraktif, kadar senyawa fenolat dan aktivitas antioksidan dari daun dewa (gynura pseudochina (1.) Dc.). Majalah Obat Tradisional 15 (1), 26-33.

Rusli, S. dan D. Darmawan, 1998. Pengaruh cara pengeringan dan tipe pengeringan terhadap mutu jahe kering. Bul. Litro 3(2) : $80-83$

Sari, D.K., D.H. Wardhani, dan A. Prasetyaningrum. 2012. Pengujian Kandungan Total Fenol Kappahycus alvarezzi Dengan Metode Ekstraksi Ultrasonic Dengan Variasi Suhu dan Waktu. Jurusan teknik kimia fakultas teknik UNDIP. Prosiding SNST ke-3 tahun 2012.Fakultas teknik Universitas Wahid Hasyim Semarang.

Schmidt S, M Zietz, M Schreiner, S Rohn, LW Kroh, dan A. Krumbein. 2009. Genotypic and climatic influences on the concentration and composition of flavonoids in Kale (Brassica oleracea var. sabellica). Food Chemistry.119: 12931299.

Siregar, R., N. Fati, S. Wahono, dan Y. Sondang. 2013. Karakterisasi daun bangunbangun (Coleus amboinicus L.) daerah Sumatera Barat. Proseding Seminar Nasional, Optimalisasi Sistem Pertanian Terpadu dan Mandiri Menuju Ketahanan Pangan. ISBN: 978-979-98691-3-5, hal 292-298, 30 Oktober 2013.

Wahyuni, R., Guswandi, Harrizal, R. 2014. Pengaruh Cara Pengeringan Dengan Oven, Kering Angina Dan Cahaya Matahari Lagsung Terhadap Mutu Simplisia Heba Sambiloto, Jurnal Farmasi Higea, Vol. 6. No. 2. 2014 